\title{
Multicultural Women’s Views on the First World War in Virginia Woolf's Mrs. Dalloway
}

\author{
Denise Borille de Abreu \\ Catholic University of Minas Gerais, Belo Horizonte, Brazil
}

\begin{abstract}
This year highlights the centenary of the outbreak of World War I and this paper aims at comparing and contrasting multicultural views on the First World War in Virginia Woolf's Mrs. Dalloway (1925). The views on the First War are portrayed by a plurality of voices, most of which are women's, and they allow readers to think of the war experience in a more subjective but also more plural way. In this novel, voices from both sides of the First War resonate, i.e., the hegemonic side of the war-the Allies - is compared and contrasted to the subjectivity of the voices of the "others"- the Axis, although they do not necessarily work in harmony. Such innovation in point of view has, in great part, contributed to converging story and history, allowing this literary work to partake in the production of historical knowledge and cultural memory of the War.
\end{abstract}

Keywords: women and war studies, English literature, the First World War, gender studies, trauma theory

If you insist upon fighting to protect me, or "our” country, let it be understood, soberly and rationally between us, that you are fighting to gratify a sex Instinct which I cannot share; to procure benefits which I have not shared and probably will not share; but not to gratify my instincts, or protect either myself or my country. For, the outside will say, in fact, as a woman, I have no country. As a woman I want no country. As a woman, my country is the whole world.

-Virginia Woolf,

Three Guineas (1938)

\section{Introduction}

The subjectivity of women's views on war is brought to a peak in Virginia Woolf's novel Mrs. Dalloway (1925). Woolf, a Bloomsbury pacifist, established herself as an important novelist, influential essayist, reviewer, and feminist critic. Mrs. Dalloway was published in 1925, the same year as Adolf Hitler's Mein Kampf, Fitzgerald's The Great Gatsby, and Kafka's The Trial.

The author hopes to show in this paper how modernist fiction's innovation in point of view has, in great part, contributed to converging story and history. Ginzsburg and Hutcheon state unanimously that in some novels by Faulkner, Woolf, Proust, and Joyce, manipulation of a single point of view makes way for a multiplicity of voices, thus stressing the subjectivity that lies between story and history. Traditional omniscient historian-narrators, who used to prevail in 19th-century novels and, therefore, conveyed one-sided views, are replaced by a multitude of voices that allow pluralistic — and multicultural—views on war and imperialism to emerge. Literary writings may convey as much historical authenticity as historical narratives, insofar as emotional and personal experience is 
also valid from the historical point of view, although it is not susceptible to traditional historical analysis.

Hutcheon (1988) refers to historiographic metafiction as containing "not one single perspective but myriad voices, often not completely localizable in the textual universe" (p. 160) and later suggests a kind of connection between the gaze or "eye" imposed by traditional narratives in opposition to the Modernist "I's", which are subjective and pluralizing (p. 161). This is true in relation to Virginia Woolf's Mrs Dalloway, where the lives and views of multicultural characters, such as Italian immigrant Rezia and German immigrant Miss Kilman, coexist with the war views of British characters Elizabeth and Clarissa Dalloway, respectively, the wealthy daughter and the housewife of a member of parliament, whose views on war, however, come very close, in terms of substance, to the intensity of an ex-soldier's drama, undergone by Septimus, and a history tutor from German ancestry, Miss Kilman, in postwar London.

The views on the First World War are portrayed by a plurality of voices, most of which are women's, and the coexistence of reports by soldiers and civilians allows readers to think of the war experience in a more subjective but also more plural way. In this novel, voices from both sides of the First War resonate, i.e., the hegemonic side of the war-the Allies—is compared and contrasted to the subjectivity of the voices of the "others"-the Axis, although they do not necessarily work in harmony.

After having witnessed the cruelty of the war, all the characters put life and death into perspective. While having to deal with the aftermath of war, they feel, however, that their lives are pointless and the strokes of the clock appear to be a kind of doom they both have to face. Before this happens, though, the characters live parallel lives, marked by the postwar psychological impact of incertitude towards the future; mostly towards the coming hours. Clarissa's perspectives on war are overlooked by her husband's political views and she feels disturbed by not being able to display her opinions, or her feeling of existential fear, at her party, intimidated by social conventions. Big Ben's tolling is frightening for it will always be a warning for a great change, either life or death. All the characters experience the wartime impact of fear and despair. No one can tell what the future will be like or if there will be one at all.

\section{The Multiplicity of Women's Voices About the First War in Mrs. Dalloway}

Woolf's association with the First War has mainly derived from her two novels Mrs. Dalloway and To the Lighthouse (1927), as well as her non-fiction work Three Guineas, published in 1938. In the first mentioned novel, though, the intricacies of the war drama lived simultaneously by a housewife and an ex-combatant, as well as the exposure of the war views of two women whose countries of origin belong to the Axis, lead us to think of the First War as a universal human experience. As a feminist activist, Woolf saw in war a series of patriarchal values through which women were oppressed and, as a pacifist, she was radically opposed to war and wrote about the wounds that victimize women, especially.

In Mrs. Dalloway, the representation of women as victims may be observed particularly in relation to the characters Lucrezia Smith and Doris Kilman. The former, an Italian immigrant in England, feels deprived of the right to express her frustration and resentment at the war. The latter, a woman of high education but belonging to a lower social class, lost her job during war. This was possibly due to her German ancestry and, in addition to the subordination to her employer, Mrs. Clarissa Dalloway, she refrains from sharing her opinions on war openly. Usui (1991) describes Woolf's views of war and patriarchal oppression as follows: 
The women who could do nothing but wait for their sons', husbands' and lovers' return are finally confronted with their deaths, yet have to continue to live with grief and pain. The war, therefore, embodies patriarchy, which oppresses women's true selves and deprives them of their voice. (p. 152)

Note that, in addition to being a foreigner, Lucrezia is in charge of assisting her shell-shocked husband, a frustrating attempt that culminated in the end of his life. Likewise, Kilman, after being "dismissed from school during war" (Woolf, 1996, p. 12) works as a tutor to Elizabeth, whose mother sees her as "a brutal monster".

Concerning the representation of women as war victims, a mythical reference, as Usui ponders, is vividly portrayed in Clarissa, too. Her identification with St. Margaret surpasses the realm of religious devotion. Usui (1991) explains that:

St. Margaret's in Mrs. Dalloway represents a dimension of women's history that has been ignored and forgotten within male-dominated history. St. Margaret's has been always in the shadow of Westminster Abbey as Clarissa is in the shadow of her husband. When Peter Walsh listens to St. Margaret's bells, he remembers Clarissa's voice "being the voice of the hostess" (Woolf, 1996, p. 74) and, at the same time, "reluctant to inflict its individuality” (Woolf, 1996, p. 74). Peter now discovers the reality of Clarissa's and understands her agony behind it. St. Margaret has played an important role throughout British history, a political "hostess” as is Clarissa. (p. 154)

Although the bell toll is described as coming from St. Margaret's, it is more likely to have resonated from Big Ben. The clock tower, rising above Westminster Palace, is closely related to the British Empire, given its physical proximity to the British Houses of Parliament. Also, its height may be read as a reinforcement of the hierarchy of power, a far more repressive symbol. ${ }^{1}$ About the British Empire and the time the First War broke out, Cornell West (1993) reminds us that: "By 1914, European maritime empires had dominion over more than half of the land and a third of the peoples in the world —almost 72 million square kilometres of territory and more than 560 million people under colonial rule” (p. 209).

Woolf was keen to explore the topics of victims and wounds as thoroughly as possible in the narrative. Although not necessarily affected by physical wounds, such as ex-soldiers who boast of their "honorable wounds", women in wartime harbored silent wounds deeply in their breasts. The word "wound”, from the Greek, trauma, as well as the themes of oppression and grief, were key elements to Woolf's writing about the war, and their resonance possibly reveals the author's desire to air them. Bazin and Lauter (1991) associate the theme of wounds both to Woolf's private life "The trauma of a series of deaths, first of immediate family and later of friends, coupled with the horror of two world wars had a similar impact on Woolf” (p. 18) and in relation to the characters in the novel:

In Mrs. Dalloway, Woolf demonstrates the cost of war not only through the suffering of Septimus and his wife but also through unhappy experiences of minor characters and through the memories and thoughts of all her characters. Woolf sets the tone of postwar English life in the first few pages of the novel. (p. 18)

It seems reasonable that the wounds felt by Lucrezia and Kilman, whose countries of origin belong to the Axis, be paralleled. What is also surprising about Woolf's novel is the conversion on the lives of an ex-soldier and a wealthy housewife. Woolf's (1980) technique of converging characters' lives is described by herself in a diary entrance: "I dig out beautiful caves behind my characters: I think that gives exactly what I want; humanity,

\footnotetext{
${ }^{1}$ Information on these and other public places in London have been confirmed by The London Encyclopaedia (Weinreb \& Hibbert, 1993).
} 
humour, depth. The idea is that the caves shall connect, and each comes to daylight at the present moment” (p. 213).

This writing process is defined by Scott (2005) as “tunneling” who reminds us that it is not until Clarissa's party, or "the culmination of the plot" (p. lvi), that the trenches connecting Clarissa and Septimus are so dramatically shared. By the time the party occurs, Septimus has already committed suicide but, by contrast, Clarissa has never felt so alive, i.e., so deeply merged in the complexity of her thoughts on human existence. Scott (2005) points out that:

The party has a ghostly visitor in the form of Septimus Smith, and having heard of his death from the Bradshaws [one of whom was Septimus' physician], Clarissa draws apart to accommodate him. She finds an affirmation of life from his throwing it away, her thoughts echoing his own feeling of the event. (p. lxvi)

Here is the point where the lives of Clarissa and Septimus are entrenched in the wounds that hurt both in silence, located in the mind, where the cost of war, that no one can precisely calculate, takes its toll. The wounds that connected both British characters may also be seen as an allusion to the collapse of the British Empire and the distress felt by the English people after the war.

Woolf's literary achievement with Mrs. Dalloway has been acclaimed by critics such as Scott and Hynes who, respectively, paired her novel with the inventiveness of Joyce's Ulysses (1993) and the poignancy of Eliot's The Wasteland (1955). Scott (2005) cites as an example “the hallucinatory dramas of the 'Circe' brothel episode” (p. liv) that, in Woolf's novel, would be relieved by different characters:

Septimus and Rezia Smith hear the repressive voice of proportion issuing from the mouth of the physician, Dr. Bradshaw. Septimus has hallucinatory episodes symptomatic of what we now call post-traumatic stress disorder, and Peter Walsh has a dream sequence, with a discourse of its own, while snoozing in the park. (p. liv)

Parallel to learning about the mysterious condition that has affected her husband's mind, the mental breakdown that could be symptoms of madness ${ }^{2}$ or “not having a sense of proportion”, in the doctor's words, Rezia struggles to understand why Septimus cannot give her a child; why she must remain in London, instead of going back to Italy and joining her mother and sister again in their happy hat-making business; why she has to suffer (Woolf, 1996, p. 54) and watch her husband's irrevocable sorrow, prompted by his comrade's death in the War, a week before the Armistice; why she, too, has to suffer because of the War.

Hynes (1991) enhances the historical vision of war in Woolf's novel, compared to and described in the same extent of vividness as in Eliot's poem:

Her subject was larger than a story of war; it was time, change, the irrevocability of loss, the ecstatic sharpness of the felt moment. But her novel is located in history, and like The Wasteland it has an historical vision. There was a time that was comfortable and happy, before war came with its cruelty and its madness, and ended all that. Now, in the world-after-the-war, the cruelty and madness remain; in the middle of the party, here's death. (p. 345)

\footnotetext{
${ }^{2}$ Concerning the psychological realism brought up by Mrs. Dalloway, Almeida's theory of "transgression" appears to be a more valid hypothesis than the speculations of "madness" by Poole and Scott. Having Woolf's essay "On Being Ill" as a basis for argumentation, she points out that Septimus and Clarissa "are already excluded from society through their 'illness"”. The author refers, respectively, to Septimus' shell-shock disorder and Clarissa's "apparently recovering from some mysterious ailment that is often mentioned throughout the novel— 'she was over fifty, and grown very white since her illness' (4)" which confined her to an attic room (Almeida, 1994).
} 
The passage elucidates how, in both novels, the modernist use of postwar subjective experiences conveys historical realism to the present moment. It illustrates, more importantly, the parallelism between literary and historical studies.

About fictional and historical narratives, the Finnish critic Pihlainen (2002) draws an interesting parallel by stating that:

In terms of metaphorical insight, the knowledge that historical narratives impart is therefore on a par with the "knowledge" that we receive from literature... That is, since both kinds of narratives provide us with "models of interpretative thought” they can both be seen as partaking in the production of knowledge. (p. 1)

It may be inferred that women war writings, especially Woolf's novel Mrs. Dalloway, can be seen as partaking in the production of historical knowledge and cultural memory of the War. The novel contributes to expanding the multicultural reality of the two sides involved in the war, through a polyphonic interplay, in which voices from the Allies and the Axis are interpolated and interrelated.

Literary experiment, in Mrs. Dalloway, is parallel with the historical vision brought by the novel. Hutcheon (1988) recalls "Woolf and Joyce’s experiments with limited, depth vision in narrative” (p. 117). Again, Woolf and Joyce "exchange hats"-it may be observed that, in modernist novels, history is re-created by means of self-consciousness and psychological realism, not necessarily by claims of objective reality. In addition, the choice for writing a stream-of-consciousness novel, more specifically by means of indirect interior monologue, represents more than innovation on style: By recording the free expressions of the human mind, Woolf centers war on the core of human experience. It may also be observed that the use of focalization, on the depicted consciousness of characters from rival countries, stresses the impact and the loss suffered by both sides after the First War.

Class conflict appears constantly in the narrative, although it is certainly more emphasized between Clarissa and Miss Kilman, to whom Clarissa refers to as "a monster”. The divergences between them may be accounted for by their different economical and marital status and, symbolically, the two women are mainly represented by their clothes and, by implication, their appearance. In this sense, Clarissa is defined as a woman who inherited values of high taste from her wealthy family, as follows:

"That is all”, she repeated, pausing for a moment at the window of a glove shop where, before the War, you could buy almost perfect gloves. And her old Uncle William used to say a lady is known by her shoes and her gloves. He had turned on his bed one morning in the middle of the War. He had said, "I have had enough". Gloves and shoes; she had a passion for gloves; but her own daughter, her Elizabeth, cared not a straw for either of them. (Woolf, 1996, p. 11)

It may be noted that Clarissa's upper-class values go back to a time before the war.

The following passage shows how Clarissa attacks her lower-class rival by describing her outfit. Again, there is a reference to the War, to the time when it took place:

Miss Kilman would do anything for the Russians, starved herself for the Austrians, but in private inflicted positive torture, so insensitive was she, dressed in a green mackintosh coat. Year in year out she wore that coat; she perspired; she was never in the room five minutes without making you feel her superiority, your inferiority; how poor she was; how rich you were; how she lived in a slum without a cushion or a bed or a rug or whatever it might be, all her soul rusted with that grievance sticking in it, her dismissal from school during the War- poor embittered unfortunate creature! (Woolf, 1996, p. 12) 
The two women diverge in social class and looks, they nurture reciprocal feelings of rivalry but they have in common love for Elizabeth Dalloway. War deprives Kilman of her job at school but renders her the role of Elizabeth's private tutor. War connects the two characters, as in another example of Woolf's "tunneling” process. Clarissa describes Kilman's coat, constantly worn by her, as if it were some kind of uniform, or war's masculinization of women' bodies, the same war that coined the term "trench coat" and saw its wearing by women. ${ }^{3}$

Another curiosity about Kilman's appearance is that her clothes are, in fact, described in a way that may resemble Greek warrior goddess Athena:

Odd it was, as Miss Kilman stood there (and stand she did, with the power and taciturnity of some prehistoric monster armoured for primeval warfare), how, second by second, the idea of her diminished, how hatred (which was for ideas, not people) crumbled, how she lost her malignity, her size, became second by second merely Miss Kilman, in a mackintosh, whom heavens knows Clarissa would have liked to help. (Woolf, 1996, p. 123)

Scott here sees an analogy to Britannia, the female symbol of the British Empire. However, it must be taken into consideration that Britannia is herself a Roman variation of Athena. Besides, the goddess after whom the kingdom was named is more likely to appear in a seated position, with trident and helmet.

It is noted that the reference to the armored goddess Athena, whose various tasks in the Homeric epics included warfare, is associated with the woman who is in charge of instructing Clarissa's daughter, Elizabeth. Apart from having an in-depth historical background, "Her knowledge of modern history was thorough in the extreme” (Woolf, 1996, p. 122). Miss Kilman is Elizabeth's tutor: "She did out of her meager income set aside so much for causes she believed in; whereas this woman did nothing, believed nothing; brought up her daughter-but here was Elizabeth, rather out of breath, the beautiful girl” (Woolf, 1996, p. 123). One of the reasons why Clarissa despises her is the possibility that her daughter's views might be influenced by Kilman, or taken forth by Elizabeth, whose taste for studies and interest for the history of her country may suggest an analogy to Elizabeth I that surpasses the homonymic realm. The following passage refers to a lesson given by the tutor, about the War:

And she talked too about the war. After all, there were people who did not think the English invariably right. There were books. There were meetings. There were other points of view. Would Elizabeth like to come with her to listen to So-and-so? (a most extraordinary-looking old man). Then Miss Kilman took her to some church in Kensington and they had tea with a clergyman. She had lent her books. Law, medicine, politics, all professions are open to women of your generation, said Kilman. But for herself, her career was absolutely ruined, and was it her fault? Good gracious, said Elizabeth, no. (Woolf, 1996, p. 127)

As the passage stresses the complicity between teacher and student, it may be inferred that the mother-daughter relationship was compromised. In terms of identity, Kilman was closer than Clarissa to

\footnotetext{
${ }^{3}$ This piece of information, which has become a kind of common-sensical allusion to World War I, turns out to have some validation: The trench-coat was designed in order to protect men fighting in the trenches from the cold. The Webster's dictionary entry confirms that: "It is a descendant of the heavy serge coats worn by British, Canadian and French soldiers in World War I. Towards the Second World War, the trench coat became part of all enlisted men's and officer's kit, especially in the American forces: the US Army, US Army Air Corps, and the US Marine Corps" (Retrieved from http://www.websters-online-dictionary.org/tr/trench+coat.html). The "Image Gallery” in the Imperial War Museum's exhibition "Women and War" displays several WWI propaganda posters with women wearing trench coats, especially those belonging to Women's Royal Naval Service and Women's Auxiliary Air Force (Retrieved from IWM's online image gallery: http://www.iwm.org.uk/upload/package/41/women/gallery4.html).
} 
Elizabeth, and the educational background she acquired with her tutor would make Elizabeth's history a more successful one, probably a doctor (Woolf, 1996, p. 133) in comparison with her tutor's, ostracized in postwar England for her German ancestry.

Another critic, Usui (1991), has associated Miss Kilman with the feminists of the British suffrage movement, who opposed war and were mobilized "in peace groups in eleven European countries by 1915” (p. 159). Usui (1991) describes Kilman as follows:

Kilman, as the most of the radical feminists against the war, has no social rank or status. She is, however, a highly educated woman. Women's higher education began to be reformed and encouraged with the establishment of Queen's College for women in London in 1848 and of Bedford College in London in 1849. (p. 160)

It may be assumed, from this passage, that Elizabeth would inherit the cultural legacy of her teacher and, as a feminist doctor, do justice to her countrywomen's tradition as military suffragettes, pioneered by Elsie Inglis and Louisa Garrett Anderson, for instance.

Through her knowledge and work, Kilman conquers the right to express herself during the lessons taught to Elizabeth. She earns the right to speak for the "other side of the war" to Elizabeth and it seems likely that the student will learn from her tutor's legacy. Kilman's "battle” is won as she assures herself what Spivak (1993) defines as: "a historical critique of your position as the investigating person, then you will see that you have earned the right to criticize, and you will be heard” (p. 197). In terms of war as cultural politics, Elizabeth's instruction by Kilman may be said to represent the forsaking of imperialistic, hegemonic views, and a new attitude towards the formulation of a pluralistic and multicultural political perspective, contrary to her parents' beliefs; a breakthrough with the imperialistic paradigm.

\section{Conclusion}

Despite the scale of mass destruction, the First War brought unprecedented work opportunities for women. Historian Keith Robbins (2002) reminds us about women's significant insertion in the workforce during the War years and presents figures that demonstrate how the number of employed women oscillated, in a comparative scale, from 1914 to the four coming years:

There were, for example, 125 women working at Woolwich Arsenal in 1914 and 25,000 in July 1917. Three and a quarter million British women were employed in July 1914 and a little under 5 million at the close of war - the expansion being most rapid in the middle years. In France by late 1918 half a million women were directly working in war industries and some 150,000 occupied secretarial and other ancillary positions in the army. Both of these figures represented a major change from the position in 1914. (p. 161)

Robbins (2002) highlights, however, that women's jobs were considered under-paid in comparison with men's. Women's lower wages generated social debate in England and they "led to awkward questions being asked about equal pay, which trade union officials found scarcely more congenial than their employers did” (p. 161).

Although women's salaries were still far from being satisfactory, the figures shown by Robbins lead us to think that career opportunities for women were in a constant raise. More importantly, debates on equal income had been launched. Having been granted possibilities of emancipation and self-support, postwar English women reveled in the idea of independence. 
In conclusion, it may be stated that, although the reality of the dominant Allies is the ground that prevails in the novel, in Mrs. Dalloway war is presented through a two-dimensional paradigm. This multiplicity of perspectives (e.g., war seen in the point of view of British people, contrasted with the point of view of immigrants from the Axis) prevents the use of what West (1993) defines as “marginalizing and reductionist ideologies" in the novel (p. 214). One thing all the characters had in common, the experience of fear and incertitude towards the future, appears to come as a result of the fact that, no matter from which side of the war their countries were fighting, they all saw, in the aftermath of the First War, the beginning of a negative shift on the European power balance, or, in the words of West (1993), the dawn of "the last European century-the last epoch in which European domination of most of the globe was uncontested and unchallenged in a substantive way-a new world seemed to be stirring” (p. 206).

\section{References}

Almeida, S. R. G. (1994). Writing from the place of the O (O) ther: The poetic discourse of transgression in the works of Virginia Woolf, Clarice Lispector and Teolinda Gersão (Unpublished doctoral dissertation). University of North Carolina, Chapel Hill.

Bazin, N. T., \& Lauter, J. H. (1991). Woolf's keen sensitivity to war: Its roots and its impact on her novels. In M. Hussey (Ed.), Virginia Woolf and war: Fiction, reality, and myth (pp. 14-39). New York: Syracuse UP.

Eliot, T. S. (1955). The waste land and other poems. Fort Washington: Harvest Books.

Ginzburg, C. (1999). History, rethoric, and proof. Walthan: Brandeis UP.

Hutcheon, L. (1988). A poetics of postmodernism: History, theory, fiction. New York: Routledge.

Hynes, S. (1991). A war imagined: The First World War and English culture (p. 345). New York: Atheneum.

Joyce, J. (1993). Ulysses. Oxford: OUP.

Pihlainen, K. (2002). The moral of the historical story: Textual differences in fact and fiction. New Literary History, 33, 39-60.

Poole, R. (1991). We all put up with you Virginia: Irreceivable wisdom about war. In M. Hussey (Ed.), Virginia Woolf and war: Fiction, reality, and myth (pp. 79-100). New York: Syracuse UP.

Robbins, K. (2002). The First World War. Oxford: OUP.

Scott, B. K. (2005). Introduction. Mrs. Dalloway (pp. xxxv-lxviii). Orlando: Harcourt.

Spivak, G. C. (1993). Questions of multiculturalism. In The cultural studies reader (p. 197). London: Routledge.

Usui, M. (1991). The female victims of the war in Mrs. Dalloway. In M. Hussey (Ed.), Virginia Woolf and war: Fiction, reality, and myth (p. 152). New York: Syracuse UP.

Weinreb, B., \& Hibbert, C. (1993). The Encyclopaedia of London. London: Macmillan.

West, C. (1993). The new cultural politics of difference. In The cultural studies reader (pp. 203-207). London: Routledge.

White, H. (1978). Tropics of discourse: Essays in cultural criticism. Baltimore: The Johns Hopkins UP.

Woolf, V. (1938). Three Guineas. New York: Harcourt, Brace, and World.

Woolf, V. (1979). The diary of Virginia Woolf (Vol I). A. O. Bell (Ed.). Fort Washington: Harvest Books.

Woolf, V. (1980). The diary of Virginia Woolf (Vol II). A. O. Bell (Ed.). Fort Washington: Harvest Books.

Woolf, V. (1989). To the lighthouse. Fort Washington: Harvest Books.

Woolf, V. (1996). Mrs. Dalloway. London: Penguin Books. 